Journal of Advanced Research in Fluid Mechanics and Thermal Sciences

Journal homepage: www.akademiabaru.com/arfmts.html ISSN: 2289-7879

\title{
Thermal Performance of an Absorber Rod Type Solar Air Collector with Single-Path Design
}

\author{
Zainab Saberi ${ }^{1, *}$, Ahmad Fudholi ${ }^{1}$, Noorlina Mohd Zainuddin ${ }^{2}$, Zahari Ibarahim², Kamaruzzaman \\ Sopian ${ }^{1}$ \\ Solar Research Energy Institute, Universiti Kebangsaan Malaysia (UKM), 43600 Bangi, Selangor, Malaysia \\ School of Applied Physics Studies, Faculty of Science and Technology, Universiti Kebangsaan Malaysia (UKM), 43600 Bangi, Selangor, Malaysia
}

\section{ARTICLE INFO}

\section{Article history:}

Received 18 May 2019

Received in revised form 5 February 2020

Accepted 9 February 2020

Available online 5 April 2020

\section{Keywords:}

solar air collector; aluminium rod; absorber plate; intensity; mass flow rate; efficiency.

\section{ABSTRACT}

\begin{abstract}
Solar air collector is a device that collects heat energy from the sun where solar energy is converted to heat energy. A good solar air collector is when it can absorb maximum heat and can reduce as minimum as heat loss possible. In this study, a solar air collector device has been designed and constructed by attaching an aluminium rod of 210 pieces with height $2 \mathrm{~cm}$ on the absorber plate to increase the heat transfer surface area. Apart from that, fin also built in the airway to increase the transfer of heat from plate absorber to air flow. There are 4 parameter of intensities value and mass flow rate is changed in this experiment which are $101.5 \mathrm{~W} / \mathrm{m}^{2}, 302.4 \mathrm{~W} / \mathrm{m}^{2}, 530.6 \mathrm{~W} / \mathrm{m}^{2}$ and 720.0 $\mathrm{W} / \mathrm{m}^{2}$ while for the mass flow rate is $0.0236 \mathrm{~kg} / \mathrm{s}, 0.0340 \mathrm{~kg} / \mathrm{s}, 0.0452 \mathrm{~kg} / \mathrm{s}$ and 0.0584 $\mathrm{kg} / \mathrm{s}$. The aim of this study was to investigate the effect of mass flow rate and the solar intensity in improving the efficiency of thermal solar collectors. The results showed that the efficiency is between $57.2 \%$ to $77.4 \%$. Maximum thermal efficiency mass flow rate recorded at $0.0584 \mathrm{~kg} / \mathrm{s}$ with solar radiation intensity of $530.6 \mathrm{~W} / \mathrm{m}^{2}$.
\end{abstract}

Copyright @ 2020 PENERBIT AKADEMIA BARU - All rights reserved

\section{Introduction}

Energy is a basic necessity of creatures on earth. All living things need energy. The more developed a country, the more energy it uses. Thus, if a country plans to develop its country, sufficient energy generation should be given due attention [1]. There are two types of energy sources, namely common energy and renewable energy.

The common source of energy is the energy that will be finished when used where it is obtained from the earth's crust such as petroleum, natural gas and coal. The source of renewable energy is continuous energy sources such as solar, wind, hydro, biomass and biogas. The source of renewable

\footnotetext{
* Corresponding author.

E-mail address: P97458@siswa.ukm.edu.my (Zainab Saberi)
}

https://doi.org/10.37934/arfmts.69.1.112 
energy has several advantages such as reducing dependence on fossil fuel sources and reducing carbon emissions on air [2].

The current shortage of existing common sources of energy raises concerns. Hence, efforts to find alternative energy sources need to be made in an environment that does not affect the development of the country, especially developing countries [1]. Solar energy is endless and a reliable source of energy that delivers sunlight freely for everyone [3]. The use of solar energy is a substitute energy source that saves even did not pollute the environment and safe to be used. Besides, solar energy is the cheapest and cleanest source of energy and available on earth [4].

Malaysia is a country that is rich with the diversity of energy resources including natural gas and fossil fuels as well as various renewable energy sources. Malaysia lies entirely within the equatorial region, between $1^{\circ}$ and $7^{\circ} \mathrm{N}$ and $100^{\circ}$ and $120^{\circ} \mathrm{E}$ [5]. Malaysia offers an abundant potential for the use of renewable energy resources, especially solar and wind power. There has been a lot of new policy, funds, investment and programs being implemented by the government although the development of renewable energy sources is still limited and not fully utilized [6]. Malaysia is gifted with a natural tropical climate with average daily solar radiation of $4.5 \mathrm{kWh} / \mathrm{m}^{2} / \mathrm{day}$ (2011) and abundant sunshine [7] for about 12h/day. Meanwhile, Fig. 1 shows Malaysia's average daily solar radiation, which is estimated as $5.15 \mathrm{kWh} / \mathrm{m}^{2} /$ day (2013) [8]. It is estimated that Malaysia's solar power is four times that of the world's fossil fuel resources [9]. The global irradiation fluctuated in the range of $2-6 \mathrm{kWh} / \mathrm{m}^{2} /$ day.

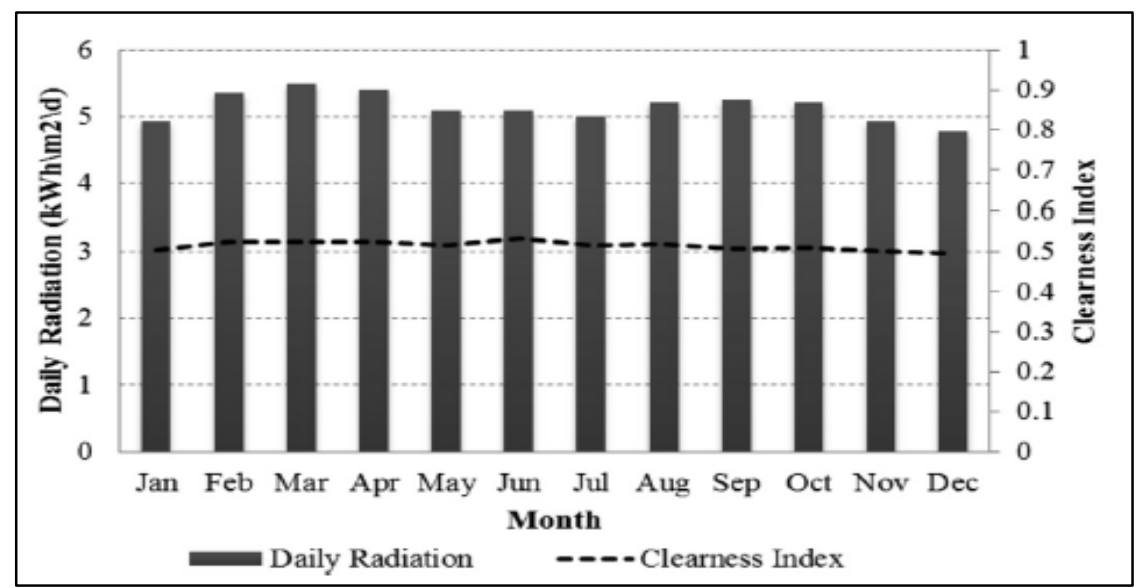

Fig. 1. Average daily radiation received in Malaysia [8]

The solar radiation in Malaysia is high relative to global standards [10]. Solar power potentially as a source of energy in Malaysia because of its experiencing a significant amount of solar radiation throughout the year. Malaysia is ideal for installing large-scale solar power due to its location in the equatorial area. Table 1 is the annual average summary of solar radiation in several cities in Malaysia [11]. Table 1 shows that Kota Kinabalu, Bayan Lepas and George Town receive the highest radiation level in Malaysia. According to the Head of Renewable Energy Unit, PTM, Penang and Sabah are the two best places to produce electricity from sunlight. 


\begin{tabular}{lc}
$\begin{array}{l}\text { Table } 1 \\
\text { Solar radiation (average } \\
\text { year) in Malaysia [11] }\end{array}$ \\
\hline \multicolumn{1}{c}{ State } & $\begin{array}{c}\text { Average value throughout } \\
\text { the year }\left(\mathrm{kWh} / \mathrm{m}^{2}\right)\end{array}$ \\
\hline Kuching & 1470 \\
Bandar Baru Bangi & 1487 \\
Kuala Lumpur & 1571 \\
Petaling Jaya & 1571 \\
Seremban & 1572 \\
Kuantan & 1601 \\
Johor Bahru & 1625 \\
Senai & 1629 \\
Kota Baru & 1705 \\
Kuala Terengganu & 1714 \\
Ipoh & 1739 \\
Taiping & 1768 \\
George Town & 1785 \\
Bayan Lepas & 1809 \\
Kota Kinabalu & 1900 \\
\hline
\end{tabular}

Figure 2 reveals that Sabah, Perlis, and Kedah have sufficient solar resources to support solar energy applications.

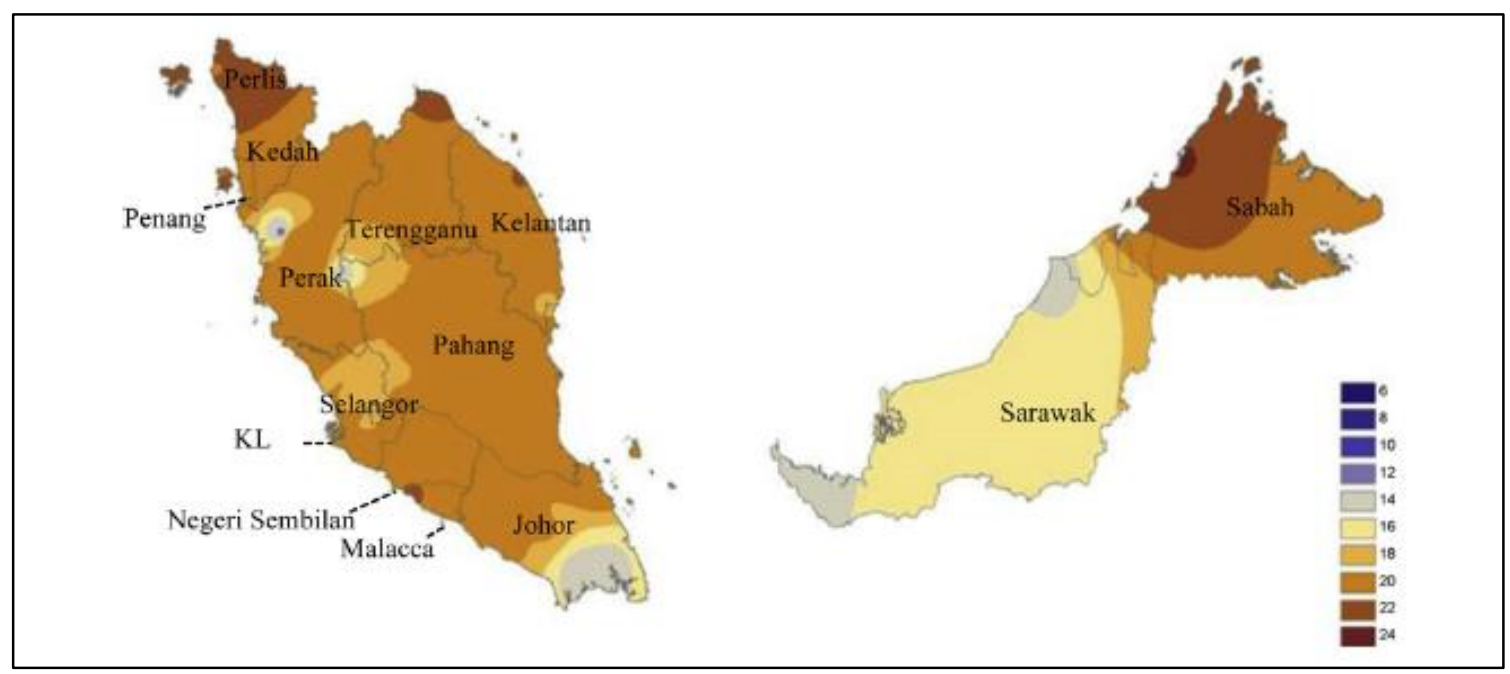

Fig. 2. Annual average solar radiation (MJ/m2/day) [11]

In a study on solar radiation in Malaysia, Sopian [12] states that the results of the study show that solar radiation in Malaysia can be divided into five patterns. The first pattern is the rays of sunny weather (only 15.7 percent), the second pattern is the solar radiation pattern that occurs on the whole day covered with clouds or rain (13.7 percent) and a ray pattern on cloudy days with uncontaminated solar radiation patterns, most days (51 percent).

It also states that there is solar radiation with its intensity can exceed the solar constant. The solar constant is the highest radiation value that can hit the earth at $1.37 \mathrm{~kW}$ per square meter at any time. The phenomenon shows that there is a single strand of light that penetrates the cloud but this is very rare (2.8 percent). This is also an important feature in weather conditions in the equator and is 
important in the process of designing photovoltaic solar systems. Also found in the solar radiation with rain in the afternoon, this phenomenon also occurs frequently (16.5 percent).

The simplest and most efficient way to use solar energy is by converting solar energy to thermal energy (thermal system). Solar thermal system is one of the potential applications of renewable energy utilization [13]. The solar thermal design is considered as one of the best cost-efficient renewable resource systems and has a big global growth potential [14]. Solar collectors are an alternative that can be used to collect energy where it can be used for specific purposes such as water heating, drying clothes, agricultural products such as paddy, cocoa, anchovies and so on.

There are various types of solar collectors that have been built such as non-convex collector, flat plate collector, evacuated tubular collector, inline-focused collector and point-focused collector. The build and structure vary depending on the temperature range to be achieved [1].

Passive and active methods are some of ways to increasing heat transfer through heat exchangers. Contrast to active techniques, passive methods do not need an external force [15]. This type of method does not use auxiliary tools such as a fan or motor to control the movement of air in the system.

Basically, the construction of a flat plate solar collector consists of transparent cover such as glass, insulation, collector frame and absorber plate. Solar radiation will penetrate through the transparent covers and sent it to the absorber plate in which heat is absorbed. Air is forced to pass through this plate using a fan and heat is collected. The side and bottom of the collector will usually be covered with insulation to reduce heat loss to other parts of collector. Figure 3 shows a schematic drawing of the heat flow through a flat plate collector [16].

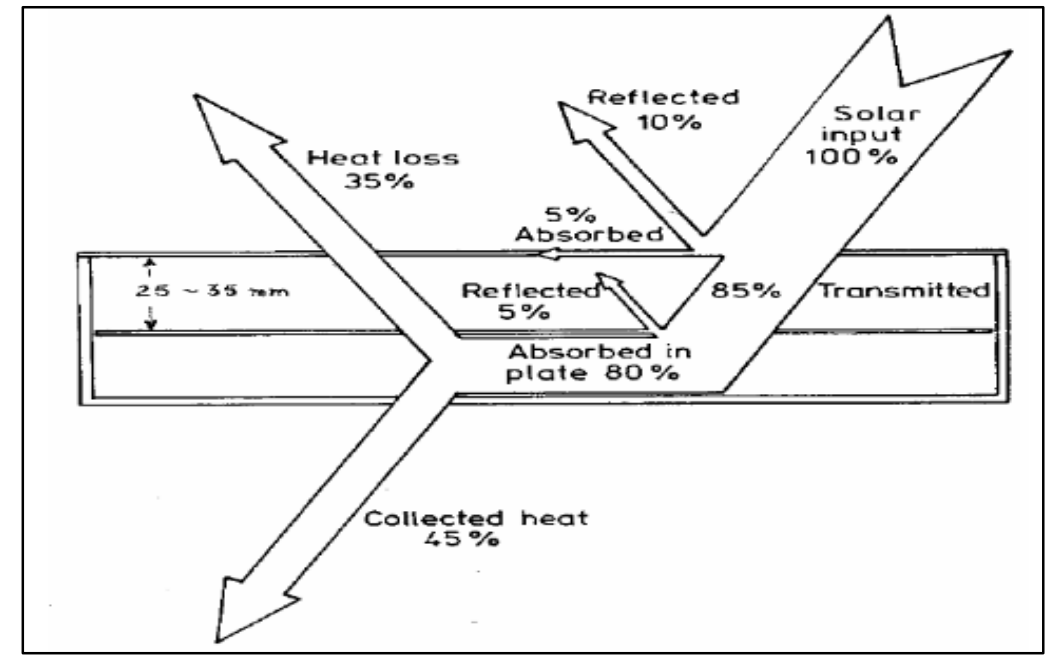

Fig. 3. Heat flow through a Flat Plate solar collector [16]

This research uses air as a medium because it is easier to handle than water even though the specific heat capacity of air is lower at $1000 \mathrm{~J} \mathrm{~kg}^{-1}{ }^{\circ} \mathrm{C}^{-1}$ than water $4186 \mathrm{~J} \mathrm{~kg}^{-1}{ }^{\circ} \mathrm{C}^{-1}$. This experiment is carried out by modifying to improve the thermal transfer coefficient between the absorber plate to the air. The modifications are made using absorber rod-type and fins are built on solar air collectors. Aluminium rod and fin are added above the surface of the absorbent plate to increase the surface area of the absorber which is exposed to solar energy and also to transfer heat rapidly over the air. Additionally, the addition of aluminium rods is to create airflow convection causes heat transfer to be efficient. 
Aluminium is chosen as a material for absorbing as it is a cheap and lightweight material compared to copper and is also a metal material that conducts thermal conducting well and is easily available in the market.

\section{Methodology}

\subsection{Model Building}

In this study, the aluminium rod-type absorber plate has been painted black dull. The aluminium rod height is $2 \mathrm{~cm}$ and a total of 210 aluminium rods are arranged on the absorber plate as shown in Figure4(a) and Figure 4(b).

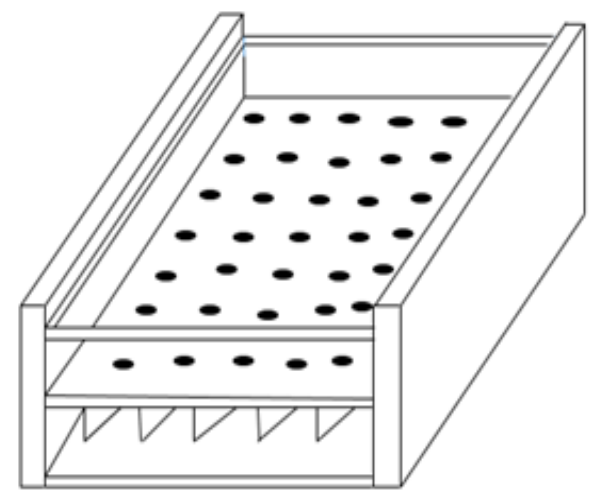

(a) Sketch of the solar collector system used

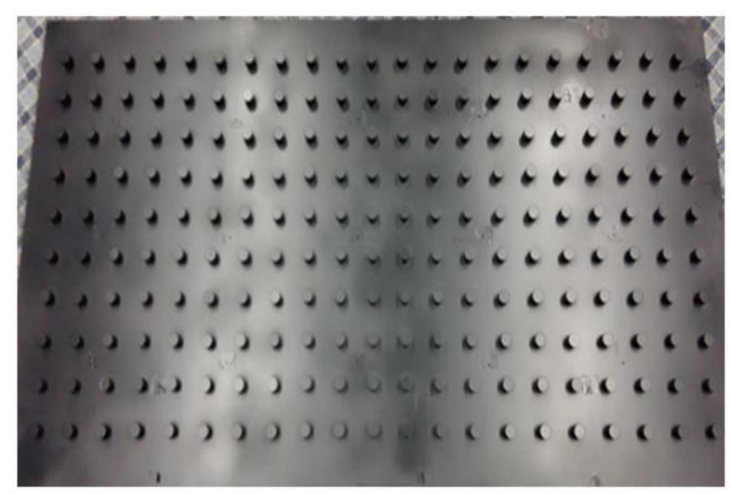

(b) Modified absorber plate

Fig. 4. Rod Type Solar Air Collector

\subsection{Acquisition Temperature Data}

The location of the thermocouples, the number of points and symbols used during the study are shown in Table 2 while Figure 5 shows the location where the thermocouples are placed on the top of the surface of the solar collector.

Table 2

Location of the thermocouples, number of points and symbols

\begin{tabular}{lcc}
\hline Thermocouple location & Number of points & Symbols \\
\hline Ambient & 1 & $T_{\mathrm{a}}$ \\
Inlet temperature & 1 & $\mathrm{~T}_{\mathrm{N}}$ \\
Backplate temperature & 3 & $\mathrm{~T}_{\mathrm{B}}$ \\
Glass cover temperature & 5 & $\mathrm{~T}_{\mathrm{G}}$ \\
Absorber plate temperature & 5 & $\mathrm{~T}_{\mathrm{P}}$ \\
Collector surface temperature & 15 & $\mathrm{~T}_{11}, \mathrm{~T}_{12}, \mathrm{~T}_{13}, \mathrm{~T}_{21}, \mathrm{~T}_{22}, \mathrm{~T}_{23}, \mathrm{~T}_{31}, \mathrm{~T}_{32}, \mathrm{~T}_{33}, \mathrm{~T}_{41}, \mathrm{~T}_{42}, \mathrm{~T}_{43}, \mathrm{~T}_{51}, \mathrm{~T}_{52}, \mathrm{~T}_{53}$ \\
Outgoing air route & 1 & $\mathrm{~T}_{\text {out }}$ \\
\hline
\end{tabular}




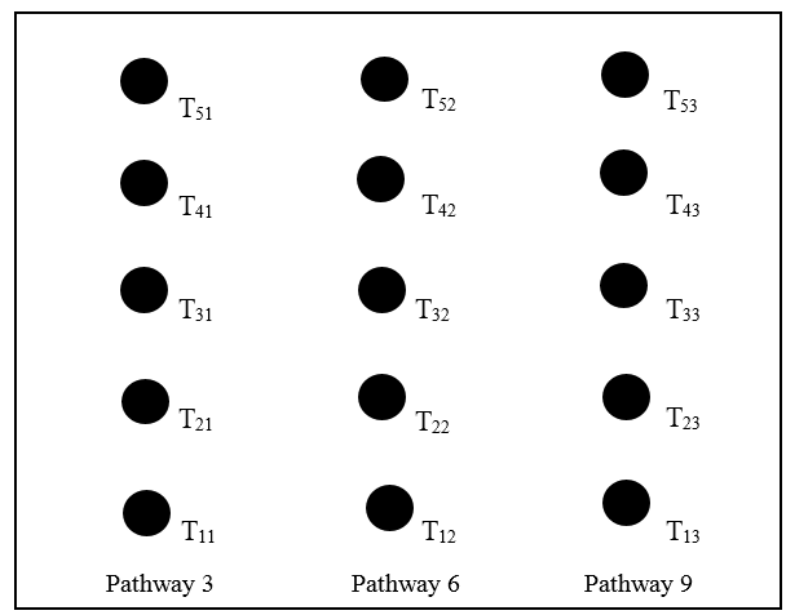

Fig. 5. A location where the thermocouples are placed on the top of the surface of the solar collector.

\subsection{Procedure for taking the temperature}

There are several steps to take during this study. Among them are solar collector tools to be placed on parallel supporter under the solar simulator. The solar collector's position is $76 \mathrm{~cm}$ from floor level and $125 \mathrm{~cm}$ from solar radiation.

After that, all K-type thermocouple should be connected to the logger data where the logger data connects to the laptop to record any temperature changes. The experiment initiated with the voltage regulator setting knob elevated to $118 \mathrm{~V}(0.0236 \mathrm{~kg} / \mathrm{s})$ and $50 \mathrm{~V}\left(101.5 \mathrm{~W} / \mathrm{m}^{2}\right)$. To determine the voltage regulator, a multimeter is used to ensure that the readings are right and accurate.

Additionally, solar simulator and fan are fitted for one hour to produce a steady solar intensity and airflow. When the system is stable, the temperature is recorded following time that had set that is for 10 minutes. Data applications that have been downloaded in the computer are used to record data for 10 minutes and are presented in the excel sheet. The time interval taken is to ensure the data obtained from this system achieve a steady state.

Subsequently, airspeed readings were taken at 12 places by using the anemometer while solar intensity reading was taken at 9 places by using the pyranometer and the reading should be recorded.

Finally, repeat the following steps with a voltage regulator at $50 \mathrm{~V}, 81 \mathrm{~V}, 103 \mathrm{~V}$ and $119 \mathrm{~V}$ for intensity and $118 \mathrm{~V}, 148 \mathrm{~V}, 175 \mathrm{~V}$ and $199 \mathrm{~V}$ for airspeed. The efficiency of each intensity and mass flow rate can be calculated by using the following formula:

$\eta_{c}=\frac{V \cdot \rho \cdot \Delta T \cdot C p}{A c \cdot I} \times 100$

where, $V$ is the volume of air through the collector $\left(\mathrm{m}^{3} / \mathrm{s}\right), \rho$ is the density of air $\left(\mathrm{kg} / \mathrm{m}^{3}\right), \Delta \mathrm{T}$ is gradient air temperature $\left({ }^{\circ} \mathrm{C}\right), C_{p}$ is the specific heat of the air $\left(\mathrm{J} / \mathrm{kg}{ }^{\circ} \mathrm{C}\right), \mathrm{A}_{c}$ is area of collector that exposed to solar radiation $\left(\mathrm{m}^{2}\right)$ and $\mathrm{I}$ is intensity of solar radiation that hit the surface of solar collector $\left(\mathrm{W} / \mathrm{m}^{2}\right)$.

\subsection{Complete System}

Figure 6 shows the complete system of solar air collectors used for experimental. Figure 7(a) shows the arrangement of experimental equipment in the laboratory from the front view and Figure 7 (b) show the side view of the solar collector. 


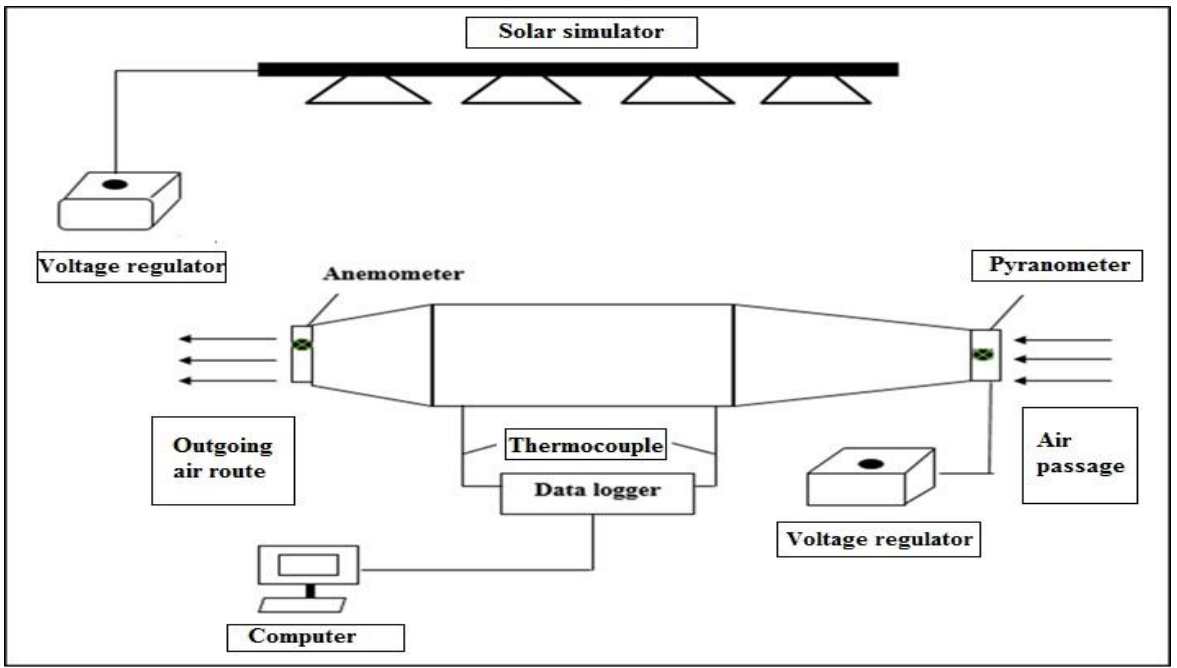

Fig. 6. The complete system of solar air collectors

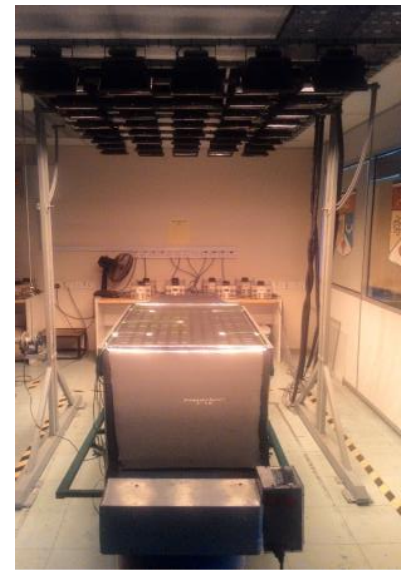

(a) Front view

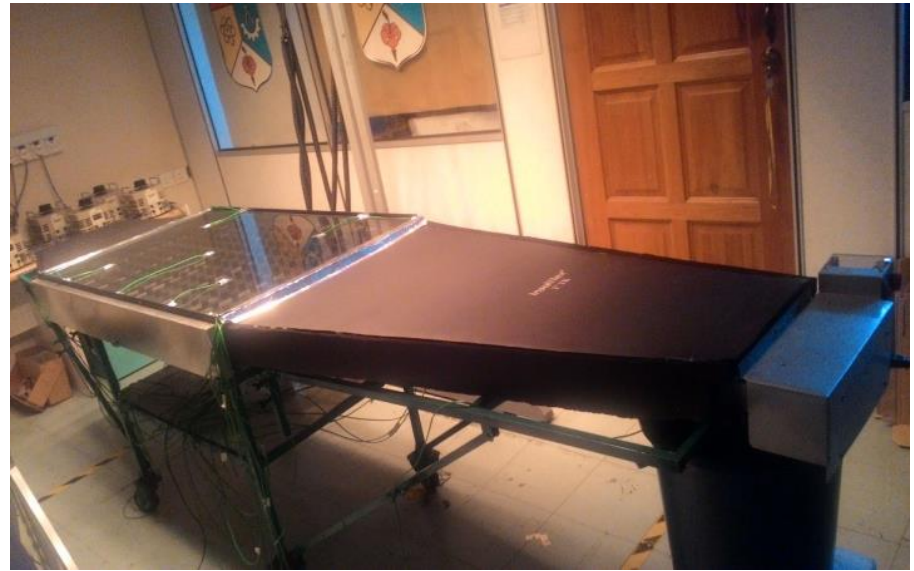

(b) Side view

Fig. 7. An arrangement of experimental equipment in the laboratory

\section{Results}

\subsection{Efficiency of Solar Collector}

\subsubsection{Graph of efficiency against mass flow rate}

Table 3 shows the thermal efficiency of solar air collectors studied at 4 mass flow rates and 4 different solar intensities.

\section{Table 3}

Thermal efficiency value, $\eta$ based on the solar intensity, $I$ and the mass flow rate, $\dot{m}$ specified

\begin{tabular}{|c|c|c|c|c|}
\hline \multirow[t]{2}{*}{$\begin{array}{l}\text { Mass } \\
\text { flow rate, } \\
\dot{m}(\mathrm{~kg} / \mathrm{s}) \\
\end{array}$} & \multicolumn{4}{|c|}{$\begin{array}{l}\text { The intensity of Radiation, I } \\
\qquad\left(\mathrm{W} / \mathrm{m}^{2}\right)\end{array}$} \\
\hline & 101.5 & 302.4 & 530.6 & 720.0 \\
\hline 0.0236 & 57.2 & 60.3 & 63.9 & 65.4 \\
\hline 0.0340 & 67.3 & 68.2 & 70.3 & 71.0 \\
\hline 0.0452 & 72.1 & 73.7 & 74.3 & 74.8 \\
\hline 0.0584 & 74.9 & 75.8 & 77.4 & 70.9 \\
\hline
\end{tabular}




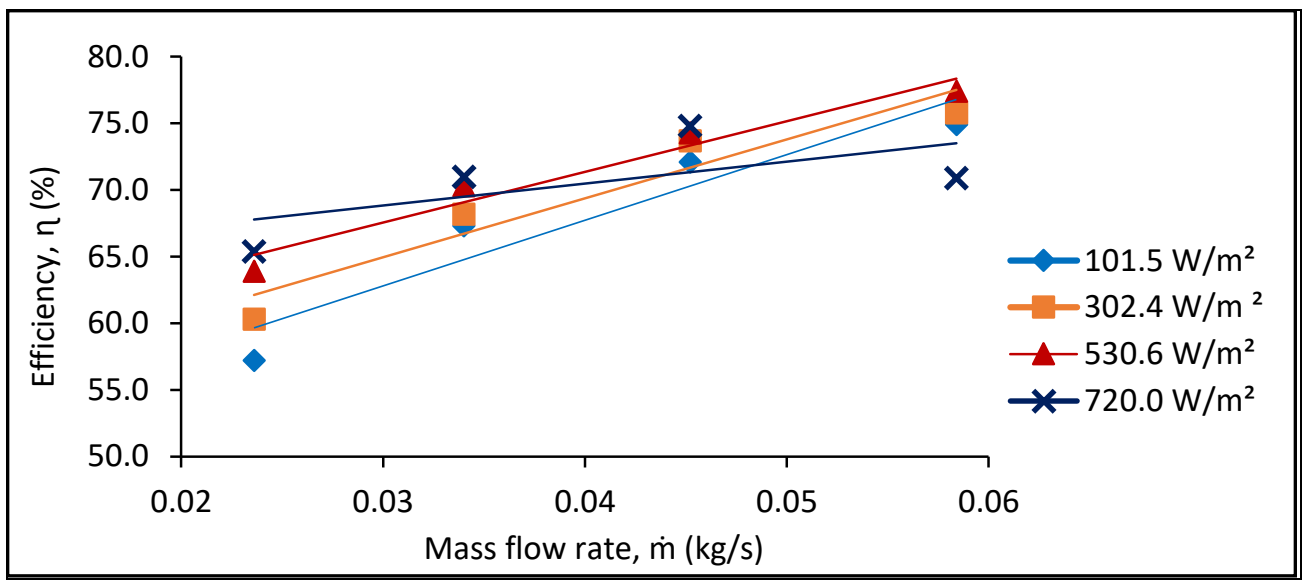

Fig. 8. Graph efficiency against the mass flow rate at different intensities

Figure 8 shows the efficiency graph against the mass flow rate at different intensities. The purpose of this study is to investigate the effects of mass flow rate and solar intensity in determining the thermal efficiency of the solar collector. The efficiency of a system will increase if the mass flow rate is also increased [17]. Based on Figure 8, the maximum efficiency of the solar collector is $77.4 \%$ on the intensity of the solar radiation $530.6 \mathrm{~W} / \mathrm{m}^{2}$ with a mass flow rate of $0.0584 \mathrm{~kg} / \mathrm{s}$. The results showed that the efficiency increased at $0.0236 \mathrm{~kg} / \mathrm{s}, 0.0340 \mathrm{~kg} / \mathrm{s}, 0.0452 \mathrm{~kg} / \mathrm{s}$ and $0.0584 \mathrm{~kg} / \mathrm{s}$ with solar intensity $101.5 \mathrm{~W} / \mathrm{m}^{2}, 302.4 \mathrm{~W} / \mathrm{m}^{2}$ and $530.6 \mathrm{~W} / \mathrm{m}^{2}$. Nevertheless, the percentage of efficiency has decreased at the intensity value of solar radiation $720.0 \mathrm{~W} / \mathrm{m}^{2}$ with the efficiency of $70.9 \%$.

The mass flow rate is very important in determining the efficiency of the solar collector as it allows the air that absorbs heat from the absorber plate to flow out well allowing the new air to absorb heat from the absorbing plate. The usage of fin structure in this experiment is very helpful in increasing the heat transfer from the absorption plate to a fluid which is air.

It is likely that the efficiency decreases as the intensity and mass flow rate are too high. This is because when the intensity is too high, it causes the air through the air duct could not absorb the heat from the collector plate well because they are saturated and causes the collector plate to be dense with heat, thus unable to absorb the heat well. Therefore, the optimum intensity of the solar collector system is at the intensity of $530.6 \mathrm{~W} / \mathrm{m}^{2}$ where it has high efficiency of $77.4 \%$. On the intensity of $720.0 \mathrm{~W} / \mathrm{m}^{2}$, the optimum efficiency is achieved at a mass flow rate of $0.0452 \mathrm{~kg} / \mathrm{s}$ of $74.8 \%$ but when the mass flow rate increases to $0.0584 \mathrm{~kg} / \mathrm{s}$, the efficiency decreases to $70.9 \%$. It shows that the system is no longer efficient in generating useful heat.

Based on Figure 8, at the lowest mass flow rate of $0.0236 \mathrm{~kg} / \mathrm{s}$, the lowest efficiency value is recorded at about $57.2 \%-65.4 \%$. This is because when the airflow passing through the airway is quite slow, the amount of heat transferred from the absorber plate to the fluid is small.

\subsubsection{Graph of efficiency against the difference out and inlet temperature against 4 different intensities.}

Summary of experimental is results summarized in Table 4. While Figure 9 shows the constant mass flow rate, the value $(\Delta T / I)$ increases as the intensity and efficiency increase, $\eta$. The slope of this line represents the rate of heat loss from the collector. For example, collectors with cover sheets will have less of a slope than those without cover sheets [18]. The difference in out and in temperature of the highest intensity is $0.0252{ }^{\circ} \mathrm{Cm}^{2} / \mathrm{W}$ recorded at a mass flow rate of $0.0236 \mathrm{~kg} / \mathrm{s}$ and intensity of $720.0 \mathrm{~W} / \mathrm{m}^{2}$. The efficiency value is also lowest at this mass flow rate. 


\section{Table 4}

Difference in temperature out and the inlet temperature / I, ( $\Delta T$ / I) based on the mass flow rate, $\dot{\mathrm{m}}$ and solar intensity, I specified.

\begin{tabular}{l|llll}
\hline $\begin{array}{l}\text { Mass flow } \\
\text { rate, } \dot{m} \\
(\mathbf{k g} / \mathbf{s})\end{array}$ & \multicolumn{4}{c}{ The intensity of radiation, I $\left(\mathbf{W} / \mathbf{m}^{\mathbf{2}}\right)$} \\
\hline & 101.5 & 302.4 & 530.6 & 720.0 \\
\hline & 0.0221 & 0.0232 & 0.0246 & 0.0252 \\
0.0236 & 0.0180 & 0.0183 & 0.0188 & 0.0190 \\
0.0452 & 0.0145 & 0.0148 & 0.0150 & 0.0151 \\
0.0584 & 0.0117 & 0.0118 & 0.0121 & 0.0110 \\
\hline
\end{tabular}

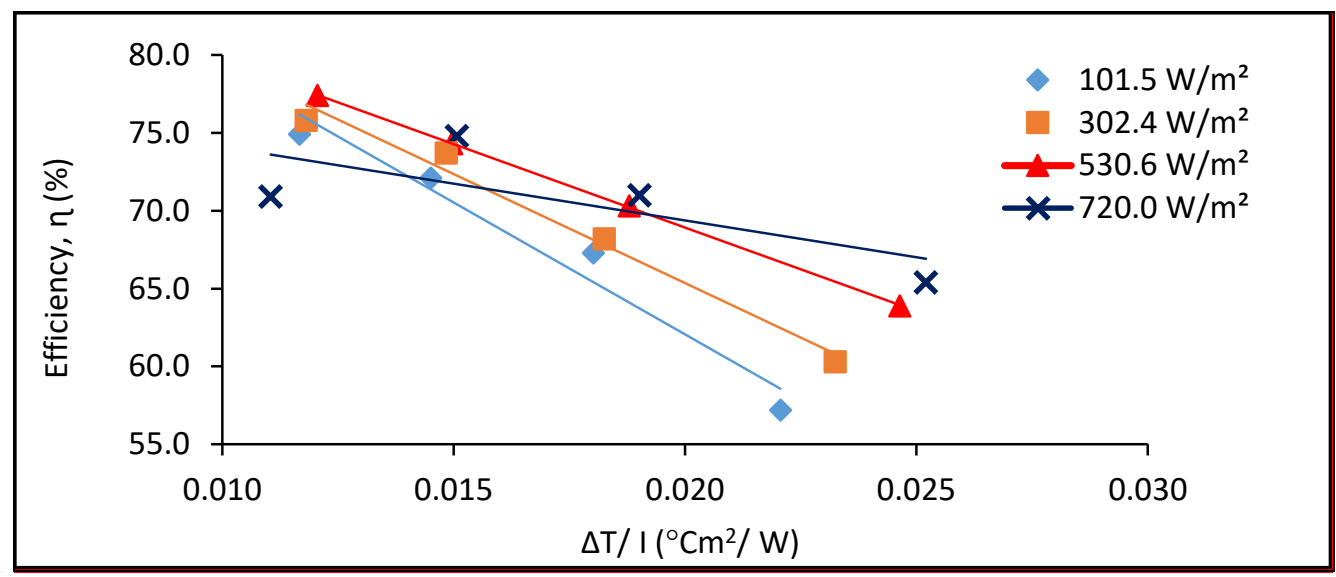

Fig. 9. Graph of efficiency against the difference out and inlet temperature against 4 different intensities.

This is due to the temperature rise through the collectors is high. This leads to higher heat loss. According to the concept of heat transfer through convection to achieve a temperature equilibrium, the heat from the heat collector plate frees much into the air cooler environment. When the absorber plate has a higher temperature than the ambient temperature, then heat transfer occurs quickly and affects the efficiency value. Therefore, high system efficiency can be achieved if the difference in and out temperature of the intensity is small.

\subsection{Mass Flow Rate}

\subsubsection{Graph of difference in temperature out and the inlet temperature against the mass flow rate}

Mass flow rate affects the air temperature through solar collectors. Therefore, Figure 10 shows the temperature difference increasingly descend with increasing mass flow rate at different intensities. This is because the mass flow rate helps in flowing air by turbulence. Therefore, lower heat losses occur and affect the efficiency of the system. At intensity $101.5 \mathrm{~W} / \mathrm{m}^{2}$, at mass flow rate of $0.0236 \mathrm{~kg} / \mathrm{s}\left(\Delta \mathrm{T}=2.2^{\circ} \mathrm{C}\right)$, efficiency is $57.2 \%$ while mass flow rate is $0.0584 \mathrm{~kg} / \mathrm{s}\left(\Delta \mathrm{T}=1.2^{\circ} \mathrm{C}\right)$ which is $74.9 \%$. The results of these experiments are summarized in Table 5. 
Table 5

Value of the difference in out and inlet temperature, $\Delta T$ ( $T$ in - $T$ out) based on the mass flow rate, $\dot{m}$ and solar intensity, I specified

\begin{tabular}{l|llll}
\hline $\begin{array}{l}\text { Mass flow } \\
\text { rate, } \dot{\mathbf{m}} \\
\mathbf{( k g / s )}\end{array}$ & \multicolumn{4}{c}{$\begin{array}{c}\text { The intensity of radiation, I } \\
\left(\mathbf{W} / \mathbf{m}^{\mathbf{2}}\right)\end{array}$} \\
\hline & 101.5 & 302.4 & 530.6 & 720.0 \\
\hline & 2.2 & 7.0 & 13.1 & 18.1 \\
0.0236 & 1.8 & 5.5 & 10.0 & 13.7 \\
0.0340 & 1.5 & 4.5 & 7.9 & 10.8 \\
0.0452 & 1.2 & 3.6 & 6.4 & 8.0 \\
0.0584 & & & & \\
\hline
\end{tabular}

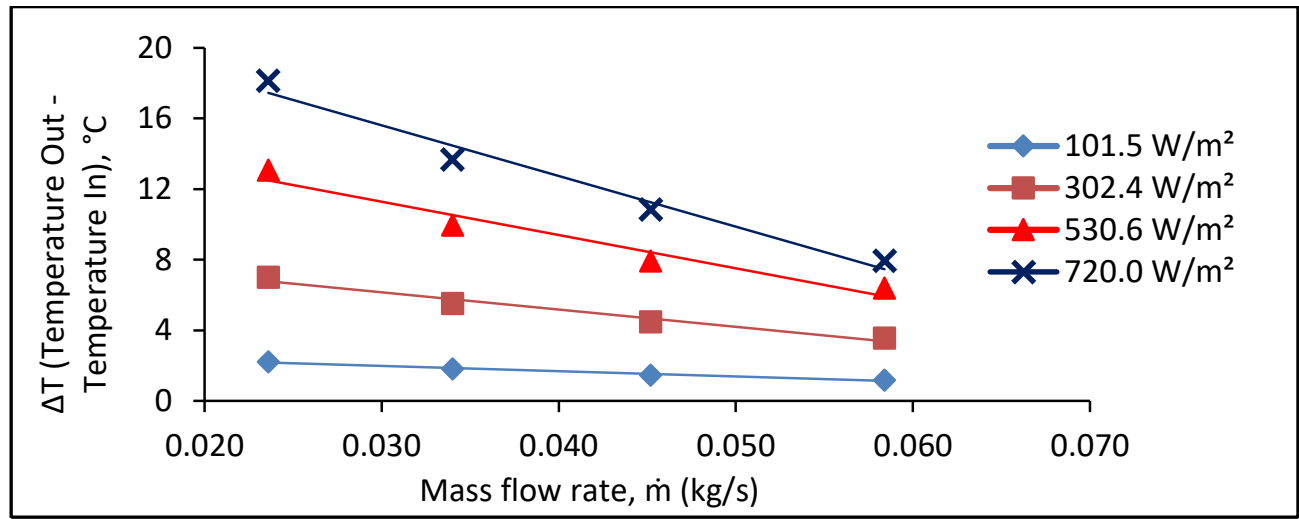

Fig. 10. Graph the difference in temperature out and the inlet temperature against the mass flow rate

\subsubsection{Graph of temperature out against mass flow rates}

The results of these experiments are summarized in Table 6. Figure 11 shows the relationship between mass flow rate and temperature out. The graph shows that the temperature out decreases with the mass flow rate increase. This proves that the slower the speed of air, the more heat it absorbs and the increased temperature of the collector can be obtained. At mass flow rate of 0.0236 $\mathrm{kg} / \mathrm{s}$ and $0.0584 \mathrm{~kg} / \mathrm{s}$ for intensity $101.5 \mathrm{~W} / \mathrm{m}^{2}$, the exit temperature is $29.9{ }^{\circ} \mathrm{C}$ and $28.5{ }^{\circ} \mathrm{C}$ respectively.

At a steady mass flow rate, the temperature out increases as the intensity increases. It is because when the intensity value increases, the more radiation that can be absorbed by the collector then absorbed by the air-fluid then out as hot air. 
Table 6

Temperature out ( $T_{\text {out }}$ ) based on the mass

flow rate, $\dot{m}$ and solar intensity, I specified

\begin{tabular}{l|llll}
\hline $\begin{array}{l}\text { Mass flow } \\
\text { rate, } \dot{\mathbf{m}} \\
\mathbf{( k g / s )}\end{array}$ & \multicolumn{4}{c}{$\begin{array}{c}\text { The intensity of Radiation, I } \\
\left(\mathbf{W} / \mathbf{m}^{\mathbf{2}} \mathbf{)}\right.\end{array}$} \\
\hline & 101.5 & 302.4 & 530.6 & 720.0 \\
\hline & 29.9 & 34.6 & 41.1 & 47.1 \\
0.0236 & 29.0 & 33.0 & 37.7 & 42.0 \\
0.0440 & 28.9 & 31.8 & 36.2 & 39.5 \\
0.0584 & 28.5 & 31.0 & 34.8 & 37.0 \\
\hline
\end{tabular}

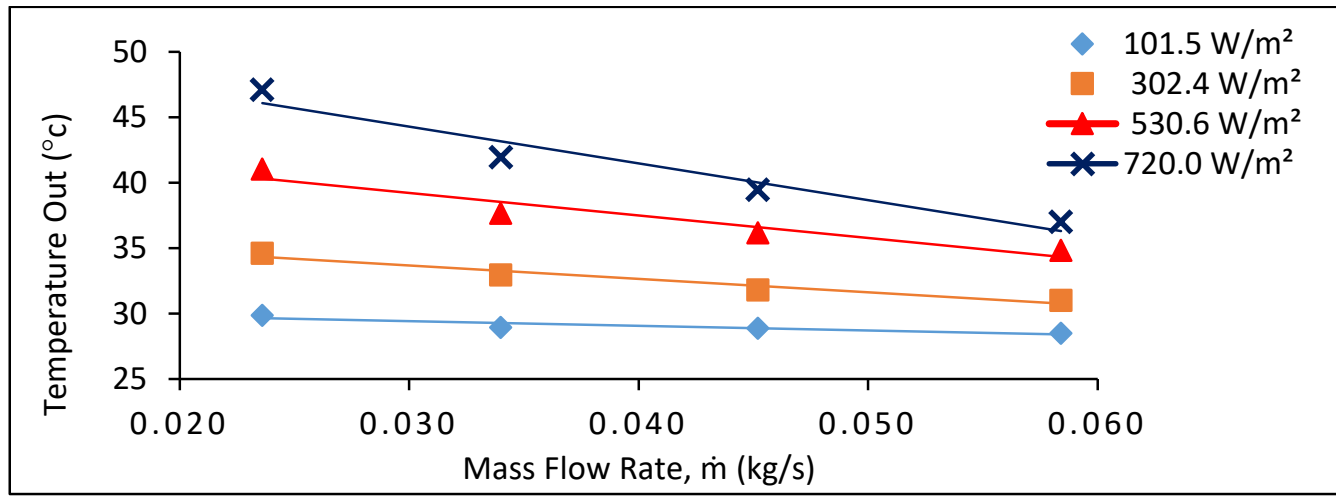

Fig. 11. Graph of temperature out against mass flow rates

\section{Conclusions}

The relationship between system efficiency and other parameters such as mass flow rate, intensity, a temperature difference of the glass cover with the ambient temperature and the difference in outgoing temperature and inlet temperature on the four different intensities can be seen and studied. Based on the data obtained and analyzed, at the highest mass flow rate of 0.0584 $\mathrm{kg} / \mathrm{s}$, it has the highest efficiency of $77.4 \%$ where the difference in temperature and inlet temperature is $6.4{ }^{\circ} \mathrm{C}$ at $530.6 \mathrm{~W} / \mathrm{m}^{2}$ intensity. It clearly shows that the efficiency of a system increases when the value of the difference in temperature of the out and inlet is smaller. Additionally, the usage of the fins and the surface of the absorber plate attached to the aluminium rod in the experiment is helpful in enhancing heat transfer from absorber plate to a fluid which is air and increases absorber surface area exposed to the intensity of the solar simulator [19]. Additionally, when high intensity is used, it will supply more heat through the radiation by solar simulates where this heat will flow well due to the high mass flow rate.

\section{Acknowledgement}

The authors would like to thank UKM for its funding (DPP-2018-002) and (GUP-2018-038).

\section{References}

[1] Othman, M. Y. H. \& Sopian, K. Teknologi Tenaga Suria. Bangi, Malaysia : Universiti Kebangsaan Malaysia, 2002.

[2] Baños, R., Manzano-Agugliaro, F., Montoya, F. G., Gil, C., Alcayde, A. \& Gómez, J. "Optimization methods applied to renewable and sustainable energy: A review." Renewable and Sustainable Energy Reviews 15, no.4 (2011): 17531766. https://doi.org/10.1016/j.rser.2010.12.008

[3] M. R. Abbas, D. Y. Dasin, and A. S. Aliyu. "Performance of Parabolic Concentrated Solar Cooker used for Cooking in Bauchi-Nigeria." Journal of Advanced Research Design 3, no.1 (2014): 9-21. 
[4] Fudholi, A., Sopian, K., Othman, M. Y., Ruslan, M. H. \& Bakhtyar, B. "Energy analysis and improvement potential of finned double-pass solar collector." Energy Conversion and Management 75 (2013): 234-240.

https://doi.org/10.1016/i.enconman.2013.06.021

[5] Mekhilefa, S., Safaria, A., Mustaffaa, W.E.S., Saidurb, R., Omara, R. \& Younisc, M.A.A. " Solar energy in Malaysia: current state and prospects." Renew. Sustain. Energy Rev. 16, no. 1 (2012): 386-396. https://doi.org/10.1016/i.rser.2011.08.003

[6] Azman, A.Y., A.A. Rahman, N.A. Bakar, F. Hanaffi and A. Khamis. "Study of renewable energy potential in Malaysia." Proceedings of the 1st Conference on Clean Energy and Technology, June 27-29, (2011): 170-176. https://doi.org/10.1109/CET.2011.6041458

[7] Solangi, K.H., Lwin, T.N.W., Rahim, N.A., Hossain, M.S., Saidur, R. and Fayaz, H. “Development of solar energy and present policies in Malaysia." Proceedings of the 1st Conference on Clean Energy and Technology, June 27-29 (2011): 115-120. https://doi.org/10.1109/CET.2011.6041447

[8] Borhanazada, H., Mekhilefa, S., Saidurb, R. \& Boroumandjazib, G. "Potential application of renewable energy for rural electrification in Malaysia." Renew.Energy 59 (2013): 210-219.

https://doi.org/10.1016/j.renene.2013.03.039

[9] Azhari, W.A., Sopian, K., Zaharim, A. \& Al ghoul, M. "A new approach for predicting solar radiation in tropical environment using satellite images e case study of Malaysia". WSEAS Trans. Environ. Dev. 4, no.4 (2008).

[10] Alsharif, M. H., Nordin, R. \& Ismail, M. "Green wireless network optimisation strategies within smart grid environments for Long Term Evolution ( LTE ) cellular networks in Malaysia.: Renewable Energy 85(2016): $157-170$. https://doi.org/10.1016/i.renene.2015.06.044

[11] Mekhilef, S., Safari, A., Mustaffa, W. E. S., Saidur, R., Omar, R. \& Younis, M. A. A."Solar energy in Malaysia: Current state and prospects." Renewable and Sustainable Energy Review 16, no.1 (2012): 386-396. https://doi.org/10.1016/i.rser.2011.08.003

[12] Sopian, K. . "Taman penyelidikan suria di UKM." Utusan Online, 14 Mei (2001).

[13] Huy, T. H. B., Nallagownden, P., Kannan, R. \& Dieu, V. N. "Energetic optimization of solar water heating system with flat plate collector using search group algorithm." Journal of Advanced Research in Fluid Mechanics and Thermal Sciences 61, no.2 (2019): 306-322.

[14] Abdullah, A. L., Misha, S., Tamaldin, N., Rosli, M. A. M. \& Sachit, F. A. "Photovoltaic thermal /solar (PVT) collector (PVT) system based on fluid absorber design: A review." Journal of Advanced Research in Fluid Mechanics and Thermal Sciences 48, no.2 (2018): 196-208.

[15] Chaji, H., Ajabshirchi, Y., Esmaeilzadeh, E., Heris, S. Z. \& Hedayatizadeh, M. Experimental Study on Thermal Efficiency of Flat Plate Solar Collector Using TiO 2 / Water Nanofluid." Modern Applied Science 7, no.10 (2013): 6069. https://doi.org/10.5539/mas.v7n10p60

[16] Klevinskis, A. \& Bučinskas, V. “Analysis of a Flat-Plate Solar Collector." Mokslas - Lietuvos ateitis 3 (2011): 39-43. https://doi.org/10.3846/mla.2011.108

[17] Alvarez, G., Arce, J., Lira, L. \& Heras, M. R. "Thermal performance of an air solar collector with an absorber plate made of recyclable aluminum cans." Solar Energy 77, no. 1 (2004): 107-113. https://doi.org/10.1016/i.solener.2004.02.007

[18] Struckmann, F. "Analysis of a Flat-plate Solar Collector. Heat and Mass Transport."(2008).

[19] Tariq, A., Altaf, K., Rani, A. M. A., Baharom, M. \& Aziz, A. R. A. "Study of heat transfer attributes of custom fins for Crank-Rocker engine block using ANSYS." Journal of Advanced Research in Fluid Mechanics and Thermal Sciences 62, no.2 (2019): 235-243. 